\title{
Geology
}

\section{Multiproxy record of abrupt sea-surface cooling across the Eocene-Oligocene transition in the Gulf of Mexico}

Bridget S. Wade, Alexander J.P. Houben, Willemijn Quaijtaal, Stefan Schouten, Yair Rosenthal, Kenneth G. Miller, Miriam E. Katz, James D. Wright and Henk Brinkhuis

Geology 2012;40;159-162

doi: $10.1130 / G 32577.1$

\section{Email alerting services}

\section{Subscribe}

\section{Permission request}

click www.gsapubs.org/cgi/alerts to receive free e-mail alerts when new articles cite this article

click www.gsapubs.org/subscriptions/ to subscribe to Geology

click http://www.geosociety.org/pubs/copyrt.htm\#gsa to contact GSA

Copyright not claimed on content prepared wholly by U.S. government employees within scope of their employment. Individual scientists are hereby granted permission, without fees or further requests to GSA, to use a single figure, a single table, and/or a brief paragraph of text in subsequent works and to make unlimited copies of items in GSA's journals for noncommercial use in classrooms to further education and science. This file may not be posted to any Web site, but authors may post the abstracts only of their articles on their own or their organization's Web site providing the posting includes a reference to the article's full citation. GSA provides this and other forums for the presentation of diverse opinions and positions by scientists worldwide, regardless of their race, citizenship, gender, religion, or political viewpoint. Opinions presented in this publication do not reflect official positions of the Society.

\section{Notes}

(C) 2012 Geological Society of America

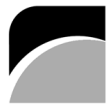

THE

GEOLOGICAL

SOCIETY

OF AMERICA 


\title{
Multiproxy record of abrupt sea-surface cooling across the Eocene- Oligocene transition in the Gulf of Mexico
}

\author{
Bridget S. Wade ${ }^{1 *}$, Alexander J.P. Houben ${ }^{2}$, Willemijn Quaijtaal ${ }^{2}$, Stefan Schouten ${ }^{3}$, Yair Rosenthal' ${ }^{1}$ Kenneth G. Miller ${ }^{4}$, \\ Miriam E. Katz ${ }^{4,5}$, James D. Wright ${ }^{5}$, and Henk Brinkhuis ${ }^{2}$ \\ ${ }^{1}$ Institute of Marine and Coastal Science, Rutgers University, New Brunswick, New Jersey 08901, USA \\ Biomarine Sciences, Institute of Environmental Biology, Utrecht University, Laboratory of Palaeobotany and Palynology, \\ Budapestlaan 4, 3584 CD Utrecht, Netherlands \\ ${ }^{3}$ Royal Netherlands Institute for Sea Research, Department of Marine Organic Biogeochemistry, P.O. Box 59, 1790 AB, Den Burg, \\ Texel, Netherlands \\ ${ }^{4}$ Department of Earth and Planetary Sciences, Rutgers University, Piscataway, New Jersey 08854, USA \\ ${ }^{5}$ Department of Earth and Environmental Sciences, Rensselaer Polytechnic Institute, Troy, New York 12180, USA
}

\section{ABSTRACT}

The Eocene-Oligocene transition (EOT; ca. 33-34 Ma) was a time of pronounced climatic change, marked by the establishment of continental-scale Antarctic ice sheets. The timing and extent of temperature change associated with the EOT is controversial. Here we present multiproxy EOT climate records ( 15-34 k.y. resolution) from St. Stephens Quarry, Alabama, $\mathrm{USA}$, derived from foraminiferal $\mathrm{Mg} / \mathrm{Ca}, \delta^{18} \mathrm{O}$, and $\mathrm{TEX}_{86}$. We constrain sea-surface temperatures (SSTs) in the latest Eocene and early Oligocene and address the issue of climatic cooling during the EOT. Paleotemperatures derived from planktic foraminifera $\mathrm{Mg} / \mathrm{Ca}$ and $\mathrm{TEX}_{86}$ are remarkably consistent and indicate late Eocene subtropical SSTs of $>28{ }^{\circ} \mathrm{C}$. There was substantial and accelerated cooling of SSTs $\left(3-4{ }^{\circ} \mathrm{C}\right)$ through the latest Eocene "precursor" $\delta^{18} O$ shift (EOT-1), prior to Oligocene Isotope-1 (Oi-1). Our multispecies planktic foraminiferal $\delta^{18} \mathrm{O}$ records diverge at the $\mathrm{E} / \mathrm{O}$ boundary $(33.7 \mathrm{Ma})$, signifying enhanced seasonality in the earliest Oligocene in the Gulf of Mexico.

\section{INTRODUCTION}

The Eocene-Oligocene transition (EOT; ca. 33-34 Ma) was a critical interval in Cenozoic climate and marks the junction from an early Paleogene 'greenhouse' world to the current 'icehouse' conditions. The EOT is associated with distinct positive steps $(>1 \%$ o) in the oxygen isotope $\left(\delta^{18} \mathrm{O}\right)$ records of deep sea benthic foraminifera (e.g., Kennett and Shackleton, 1976; Miller et al., 1991; Zachos et al., 1996; Coxall et al., 2005). The largest $\delta^{18} \mathrm{O}$ increase, commonly referred to as Oligocene Isotope-1 (Oi-1; Miller et al., 1991) represents the establishment of continental-scale Antarctic ice sheets, further indicated by a significant drop in global sea level and an increase in ice-rafted debris in the Southern Ocean (Kennett and Shackleton, 1976; Miller et al., 1991; Zachos et al., 1996). The EOT is also characterized by extinctions and assemblage changes in marine and terrestrial fauna and flora (e.g., Prothero et al., 2003), a major deepening of the calcite compensation depth (van Andel and Moore, 1974; Coxall et al., 2005), terrestrial cooling (Zanazzi et al., 2007), changes in atmospheric circulation (Xiao et al., 2010), increased aridification (Dupont-Nivet et al., 2007) and seasonality (Ivany et al., 2000; Eldrett et al., 2009). The shift from greenhouse to icehouse mode was rel-

\footnotetext{
*Current address: School of Earth and Environment, University of Leeds, Woodhouse Lane, Leeds LS2 9JT, UK; E-mail: b.wade@leeds.ac.uk.
}

atively rapid (<300 k.y.), and likely associated with a minimum in Earth's long-term obliquity and eccentricity cycles (Coxall et al., 2005).

Situated on the northwestern perimeter of the tropical Atlantic Ocean, the Gulf of Mexico is part of the Western Hemisphere Warm Pool, which through the boreal summer is the principal heat source for the Western Hemisphere extratropics (Wang and Enfield, 2001). Thus, variations in Gulf of Mexico sea-surface temperatures (SSTs) can potentially impact heat transport and high latitude temperatures and vice versa. Detailed reconstructions of the evolution of ocean temperature, and particularly subtropical/tropical SST, are essential to understand climate forcing mechanisms involved and the distribution of oceanic heat during the early stages of cryosphere development. Climate modeling experiments and $\mathrm{CO}_{2}$ proxies suggest that decreasing atmospheric $\mathrm{CO}_{2}$ may have been the primary mechanism for cooling and ice volume increase (DeConto and Pollard, 2003; Pearson et al., 2009). However, there are considerable differences in the scale of marine and terrestrial temperature change through the EOT; ranging from negligible (e.g., Kobashi et al., 2001; Kohn et al., 2004; Grimes et al., 2005; Sheldon, 2009) to more than $5{ }^{\circ} \mathrm{C}$ (e.g., Zanazzi et al., 2007; Schouten et al., 2008; Liu et al., 2009). Marine sediments containing sufficiently well-preserved planktic foraminifera and organic matter through the EOT are rare. No consensus has yet been reached on the extent of temperature change (notably cooling) and whether high latitudes cooled significantly while the tropics remained relatively unaffected.

Here, we document the timing and magnitude of temperature change in the Gulf of Mexico during the EOT by presenting a multiproxy subtropical SST reconstruction ( 15-34 k.y. resolution) from the St. Stephens Quarry (SSQ) corehole, Alabama, United States. This site contains well-preserved microfossils that have not been fully utilized yet for their paleoclimatic geochemical signatures, and thus provides the opportunity to investigate the transition from a hothouse to icehouse world, and to document major steps in climate evolution. Temperatures are constrained through independent proxies; the $\mathrm{Mg} / \mathrm{Ca}$ of well-preserved planktic foraminifera and the record of archaeal derived glycerol dialkyl glycerol tetraethers (GDGTs, expressed as the TetraEther index of 86 carbon atoms, TEX $_{86}$ ).

\section{METHODS AND PROCEDURES}

St. Stephens Quarry corehole, Alabama (31 ${ }^{\circ} 33^{\prime} \mathrm{N}, 8^{\circ} 02^{\prime} \mathrm{W}$; paleodepth 50-100 m; Miller et al., 2008) is a classic locality for bio-, litho- and sequence-stratigraphic studies of the EOT (e.g., Mancini and Waters, 1986; Keigwin and Corliss, 1986; Miller et al., 2008). Deposition occurred continuously above the lysocline and the sediments are rich in both organic molecular- and microfossils and carbonate microfossils and macrofossils, in contrast to many open ocean deep-sea sites. The well-preserved molecular- and microfossils at this site allow a multiproxy approach that can be tied to previous studies of lithologic, temperature, and sea-level changes (Miller et al., 2008; Katz et al., 2008). Geochemical analyses were conducted on the SSQ corehole from 23 to $52 \mathrm{~m}$ (76-170 ft), spanning the Marianna Formation to the Pachuta Marl Formation (lower Oligocene-upper Eocene; ca. 32-35 Ma).

Stratigraphic control for the SSQ corehole is derived from stable isotope- and magneto-stratigraphy, coupled with planktic foraminiferal, 
calcareous nannofossil and dinoflagellate biostratigraphy (see the GSA Data Repository ${ }^{1}$ for details). A study of the archive core in conjunction with newly generated stable isotope and organic walled dinoflagellate cyst (dinocyst) assemblage data has led us to revise the previously published age model of Miller et al. (2008) and Katz et al. (2008). Our revised age model indicates that the SSQ corehole does not fully capture the base of Chron $\mathrm{C} 13 \mathrm{n}$ and thus the $\delta^{18} \mathrm{O}$ excursion representing Oi- 1 , due to an $\sim 200$ k.y. hiatus (Fig. 1).

To reconstruct changes in temperature and water column structure in the Gulf of Mexico, planktic foraminifera Turborotalia ampliapertura were picked (250-300 $\mu \mathrm{m}$ size fraction) for stable isotope and trace element analyses. Stable isotope analyses were also performed on Pseudohastigerina naguewichiensis (63-125 $\mu \mathrm{m}$ size fraction) and Hantkenina spp. (250-355 $\mu \mathrm{m}$ size fraction). Details of foraminiferal pres- ervation and geochemical methods are available in the Data Repository.

The calculation of SSTs from T. ampliapertura $\mathrm{Mg} / \mathrm{Ca}$ follows Lear et al. (2008). We use the multispecies equation of Anand et al. (2003) and a $\mathrm{Mg} / \mathrm{Ca}$ seawater ratio of $4.3 \mathrm{mmol} / \mathrm{mol}$ (Wilkinson and Algeo, 1989). A +0.7 ${ }^{\circ} \mathrm{C} \mathrm{SST}$ correction is applied to T. ampliapertura paleotemperatures to account for the $\sim 0.18 \%$ o $\delta^{18} \mathrm{O}$ offset between this taxon and uppermost mixedlayer dwellers P. naguewichiensis (Tables DR2 and DR3) in the Data Repository.

The uncertainty in estimating the temperature change during the EOT with planktic foraminiferal $\mathrm{Mg} / \mathrm{Ca}$ is about $\pm 1.5^{\circ} \mathrm{C}(\sigma 1)$, largely due to the variability among replicated samples (estimated here to be $\sim 1^{\circ} \mathrm{C}$ ) and the error associated with the temperature sensitivity of the calibration $\left(1.2^{\circ} \mathrm{C}\right.$; Anand et al., 2003). Although we cannot determine the temperature sensitivity of the extinct species, T. ampliapertura, it is likely that the uncertainty in the modern multispecies calibration is applicable to extinct taxa. The uncertainty in estimating absolute SST is, however, significantly larger, as it is also confounded by the uncertainty in the $\mathrm{Mg} / \mathrm{Ca}$ of the contemporaneous seawater. While different models suggest substantially different seawater ratios for the Eocene, e.g., $4.3 \mathrm{mmol} / \mathrm{mol}$ (Wilkinson and Algeo, 1989) and $2 \mathrm{mmmol} / \mathrm{mol}$ (Demicco et al., 2005) we note that much lower ratios than the one chosen here yield unreasonably high SSTs. Within these constraints, we estimate the combined error for the absolute SSTs to be about $\pm 2.2{ }^{\circ} \mathrm{C}$.

Forty-one samples were investigated for $\mathrm{TEX}_{86}$ indices and transformed to mean annual SSTs following the temperature calibration model $\left(\mathrm{TEX}_{86}{ }^{\mathrm{H}}\right)$ of Kim et al. (2010). This calibration model is based on a large core tope data set that excludes data from (sub)polar environments. There is no reason to assume that the

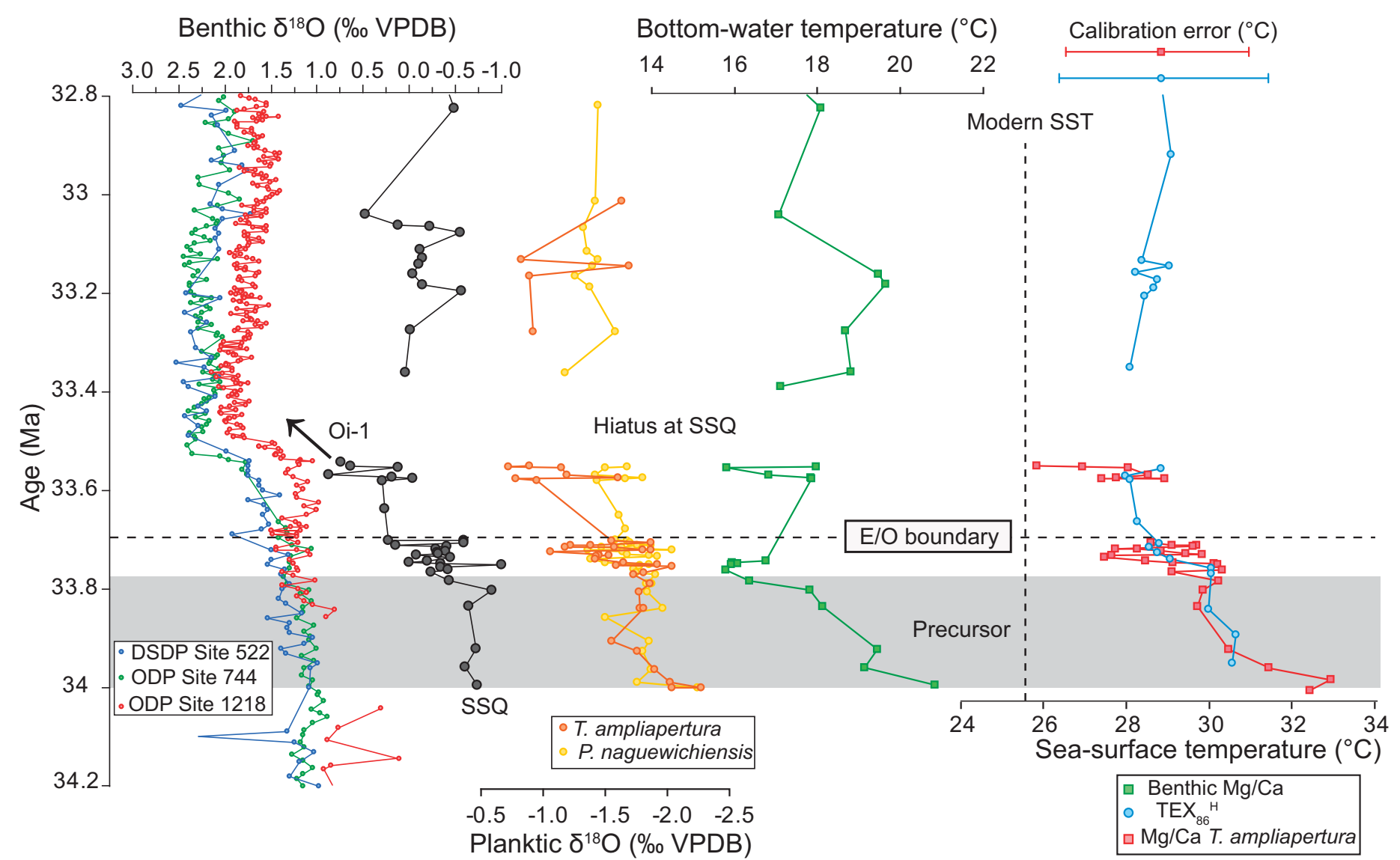

Figure 1. Oxygen isotope and multiproxy paleotemperatures across the Eocene-Oligocene transition (EOT). Planktic foraminiferal Mg/Ca and $\mathrm{TEX}_{86}$ sea-surface temperature (SST) from St. Stephens Quarry (SSQ; Alabama, USA) (this study) are remarkably consistent and indicate a substantial decline in SSTs through the EOT. Benthic foraminiferal $\delta^{18} \mathrm{O}$ record from Deep Sea Drilling Project (DSDP) Site 522, Ocean Drilling Program (ODP) Sites 744 and 1218 (Zachos et al., 1996; Coxall et al., 2005); Benthic foraminiferal $\delta^{18} \mathrm{O}$ and Mg/Ca temperatures from SSQ (Katz et al., 2008); Multispecies planktic foraminiferal $\delta^{18} \mathrm{O}$ record (this study); Shaded area indicates the precursor $\delta^{18} \mathrm{O}$ shift (EOT-1) in the latest Eocene. The calibration error for reconstructed temperatures is $\sim 2.5^{\circ} \mathrm{C}$ for $\mathrm{TEX}_{86}\left(\mathrm{TEX}_{86}{ }^{\mathrm{H}} ; \mathrm{Kim}^{\mathrm{et}} \mathrm{al}\right.$., 2010$)$ and $\sim 2.2{ }^{\circ} \mathrm{C}$ for $\mathrm{Mg} / \mathrm{Ca}$. T.-Turborotalia; P.-Pseudohastigerina.

${ }^{1}$ GSA Data Repository item 2012048, age model, methods, Figures DR1-DR5, and Tables DR1-DR4, is available online at www.geosociety.org/pubs/ft2012.htm, or on request from editing@ geosociety.org or Documents Secretary, GSA, P.O. Box 9140, Boulder, CO 80301, USA. 
temperature dependency of the archaeal lipid distribution in the Eocene/Oligocene Gulf of Mexico was substantially different in the modern Gulf of Mexico, as might be the case for the high latitudes and the application of the $\operatorname{TEX}_{86}{ }^{\mathrm{L}}$ calibration model. Samples with a branched isoprenoid tetraether (BIT) index (Hopmans et al., 2004) with values $>0.4$ were discarded, since this may point toward elevated input of GDGTs from soil organic matter and may have obscured TEX $_{86}$ paleothermometry (Weijers et al., 2006). About half of the analyzed samples were run in duplicate, the reproducibility is better than 0.5 ${ }^{\circ} \mathrm{C}$, and in most cases better than $0.25{ }^{\circ} \mathrm{C}$. The residual standard error for the $\mathrm{TEX}_{86}{ }^{\mathrm{H}}$ calibration model is $2.5^{\circ} \mathrm{C}$ (Kim et al., 2010). All data are available in the Data Repository.

\section{RESULTS AND DISCUSSION}

The agreement between the molecular organic and foraminiferal based SSTs is remarkable in terms of trends and absolute temperatures (commonly within $0.6{ }^{\circ} \mathrm{C}$; Fig. 1). We emphasize that these proxies are derived independent from one another. Uncertainties in the SST estimates include the effects of seasonality and depth habitat of archaea and the $\mathrm{Mg} / \mathrm{Ca}$ of seawater, however, our results provide renewed confidence in these proxies for reconstructing paleo-SSTs.

\section{Substantial Cooling through the EOT}

Despite its subtropical location, the Gulf of Mexico was not insensitive to temperature change across the EOT. Reconstructed SSTs are between $26 \pm 2.2{ }^{\circ} \mathrm{C}$ and $33 \pm 2.2{ }^{\circ} \mathrm{C}$ (Fig. 1), which are warmer than modern $\left(25.8^{\circ} \mathrm{C}\right.$; Rayner et al., 2003). A pronounced $\left(3-4{ }^{\circ} \mathrm{C}\right)$ reduction in SST occurred in the latest Eocene from 34.0 to 33.7 Ma. This cooling is associated with the "precursor" $\delta^{18} \mathrm{O}$ increase (EOT-1). The significant fall in temperatures recorded in planktic and benthic foraminiferal $\mathrm{Mg} / \mathrm{Ca}$ and $\mathrm{TEX}_{86}$ through the latest Eocene supports the hypothesis that EOT-1 was a time of major climatic cooling and corroborates that the first $\delta^{18} \mathrm{O}$ increase was mainly driven by a reduction in temperature and not an expansion of Antarctic ice volume (Katz et al., 2008; Lear et al., 2008; Pusz et al., 2011). Still, the EOT-1 culminates in an inferred sequence boundary within the Pachuta Marl Member of the Yazoo Formation designated SB2 (Fig. DR3 in the Data Repository). This suggests that a relatively minor ( $25 \mathrm{~m}$ ) sea-level fall was associated with EOT-1, versus the large ( 60-70 m) change associated with Oi-1 (Miller et al., 2009; Pusz et al., 2011). A similar pattern was also identified in the Priabonian Type Section in northeastern Italy (Houben et al., 2011).

The magnitude of cooling across the EOT at low and mid latitudes has been contentious. Zanazzi et al. (2007) report an $8{ }^{\circ} \mathrm{C}$ cooling in central North America. Liu et al. (2009) found inconsistent cooling for low-latitudes, and Lear et al. (2008) recorded a $2.5^{\circ} \mathrm{C}$ cooling in the western Indian Ocean (Tanzania) at EOT-1, but no cooling at Oi-1. At SSQ, we find extensive cooling $\left(3-4{ }^{\circ} \mathrm{C}\right)$ in surface and bottom waters through EOT-1. In the early Oligocene, and associated with the onset of the Oi-1 glaciation (ca. 33.55 Ma), planktic foraminiferal $\mathrm{Mg} / \mathrm{Ca}$ indicate a further decrease in temperatures of $2{ }^{\circ} \mathrm{C}$ (Fig. 1). Unfortunately the resolution of the $\mathrm{TEX}_{86}$ record and hiatus at SSQ prevents further constraints on SST change during this interval of major $\delta^{18} \mathrm{O}$ increase. The amount of cooling in the planktic foraminiferal $\mathrm{Mg} / \mathrm{Ca}$ record across the EOT is inconsistent with the $P$. naguewichiensis $\delta^{18} \mathrm{O}$ increase of $0.77 \%$ o (equivalent to a maximum of $3{ }^{\circ} \mathrm{C}$ if no change in seawater $\delta^{18} \mathrm{O}$ is inferred). We attribute additional mechanisms (such as amplified seasonality) to have influenced paleotemperatures in the Gulf of Mexico.

\section{Enhanced Seasonality}

While the season of growth in extinct populations of planktic foraminifera is unknown, we can infer seasonal preference and/or depth habitat through multispecies stable isotope analysis and comparison with other temperature proxy data. $P$. naguewichiensis consistently records the most negative $\delta^{18} \mathrm{O}$ in comparison to the rest of the assemblage (Wade and Pearson, 2008), suggesting a preference for summer upper mixed-layer calcification. The more positive $\delta^{18} \mathrm{O}$ values of $T$. ampliapertura indicate this species either calcified in a deeper mixed-layer habitat or exhibited a cooler season of growth. There is excellent agreement $\left(0.6{ }^{\circ} \mathrm{C}\right)$ between T. ampliapertura $\mathrm{Mg} / \mathrm{Ca}$ and $\mathrm{TEX}_{86}$ paleotemperatures, the latter of which are thought to represent mean annual SST (Kim et al., 2010). Thus we infer that T. ampliapertura and P. naguewichiensis $\delta^{18} \mathrm{O}$ reflect mean annual and summer SSTs, respectively.

P. naguewichiensis and T. ampliapertura $\delta^{18} \mathrm{O}$ values are fairly consistent with each other from 34 to $33.7 \mathrm{Ma}$. However, from $33.7 \mathrm{Ma}$, the records deviate and the $\delta^{18} \mathrm{O}$ offset increases to a maximum of $1 \%$ at $33.55 \mathrm{Ma}$ (Fig. 1), indicating a temperature difference between the populations of $4{ }^{\circ} \mathrm{C}$. The divergence in $\delta^{18} \mathrm{O}$ between these species is associated with an increase in benthic foraminiferal $\delta^{18} \mathrm{O}$ of $1 \%$ (Fig. 1). We attribute the deviation in $\delta^{18} \mathrm{O}$ between $P$. naguewichiensis and T. ampliapertura to reflect expansion of the thermocline and a much more stratified water column, or a change in seasonal mixed-layer temperatures. From the EoceneOligocene boundary a reduction in mean annual SSTs occurred, while summer maxima remained fairly constant, indicating enhanced seasonality or variations in atmospheric circulation leading to stronger cold continental air masses impacting the region. Our results are consistent with previous studies of otoliths from the Paleogene of the Gulf of Mexico (Ivany et al., 2000) that suggested a $4{ }^{\circ} \mathrm{C}$ cooling of winter temperatures and increased seasonality across the EOT.

As the amount of SST change in the Gulf of Mexico may in part be influenced by changes in seasonality, it is critically important to separate the global versus regional signals in SST change prior to using these records to determine global ice volume. The planktic foraminiferal $\delta^{18} \mathrm{O}$ records at SSQ can be directly compared to Tanzania (Pearson et al., 2008; Wade and Pearson, 2008). T. ampliapertura $\delta^{18} \mathrm{O}$ values from Tanzania are commonly depleted by $0.8 \%$ compared to SSQ. TEX ${ }_{86}$ and $\mathrm{Mg} / \mathrm{Ca}$ do not support that the difference in foraminiferal $\delta^{18} \mathrm{O}$ between these locations is due to temperature. Alternative explanations include preservational bias at SSQ or higher seawater $\delta^{18} \mathrm{O}$ in the Paleogene Gulf of Mexico, due to increased salinity.

Some previous studies (e.g., Ivany et al., 2000; Kobashi et al., 2001; Kohn et al., 2004; Grimes et al., 2005; Sheldon, 2009) have suggested that temperature did not notably change through the EOT. We find a substantial decrease in SSTs $\left(>3{ }^{\circ} \mathrm{C}\right)$ in the Gulf of Mexico. Our study emphasizes that subtropical temperatures were not consistently warm or stable but reduced significantly during a relatively short interval (EOT-1).

\section{SUMMARY AND CONCLUSIONS}

Our SSTs derived from independent organic molecular and foraminiferal based geochemical proxies are remarkably consistent and indicate the Gulf of Mexico was warmer than modern during the EOT. All proxies indicate a substantial drop in SSTs of $3-6{ }^{\circ} \mathrm{C}$ through the EOT. Our data support that EOT-1 primarily reflects cooling. A divergence in interspecific planktic foraminiferal $\delta^{18} \mathrm{O}$ values at the $\mathrm{E} / \mathrm{O}$ boundary indicates changes in surface water conditions and amplified seasonality in the earliest Oligocene, possibly driven by changes in atmospheric conditions resulting in cold, continental air masses impacting the Gulf of Mexico.

\section{ACKNOWLEDGMENTS}

We thank J. Browning, N. Sou, M. Chong, A. Mets, N. Welters, and J. Ossebaar for assistance and technical support, and E. Mancini for discussion. Two anonymous reviewers and V. Bowman provided valuable comments that notably improved the manuscript. This research was supported by the U.S. National Science Foundation (grant OCE06-23256), the Natural Environment Research Council (grant NE/ G014817/1), Statoil, and a Lindemann Fellowship from the English Speaking Union.

\section{REFERENCES CITED}

Anand, P., Elderfield, H., and Conte, M.H., 2003, Calibration of $\mathrm{Mg} / \mathrm{Ca}$ thermometry in planktonic foraminifera from a sediment trap time 
series: Paleoceanography, v. 18, p. 1050, doi:10.1029/2002PA000846.

Coxall, H.K., Wilson, P.A., Pälike, H., Lear, C.H., and Backman, J., 2005, Rapid stepwise onset of Antarctic glaciation and deeper calcite compensation in the Pacific Ocean: Nature, v. 433, p. 53-57, doi:10.1038/nature03135.

DeConto, R., and Pollard, D., 2003, Rapid Cenozoic glaciation of Antarctica induced by declining $p \mathrm{CO}_{2}$ : Nature, v. 421, p. 245-249, doi:10.1038/ nature01290.

Demicco, R.V., Lowenstein, T.K., Hardie, L.A., and Spencer, R.J., 2005, Model of seawater composition for the Phanerozoic: Geology, v. 33, p. 877-880, doi:10.1130/G21945.1.

Dupont-Nivet, G., Krijgsman, W., Langereis, C.G., Abels, H.A., Dai, S., and Fang, X., 2007, Tibetan plateau aridification linked to global cooling at the Eocene-Oligocene transition: Nature, v. 445, p. 635-638, doi:10.1038/ nature05516.

Eldrett, J.S., Greenwood, D.R., Harding, I.C., and Huber, M., 2009, Increased seasonality through the Eocene to Oligocene transition in northern high latitudes: Nature, v. 459, p. 969-973, doi:10.1038/nature08069.

Grimes, S.T., Hooker, J.J., Collinson, M.E., and Mattey, D.P., 2005, temperatures of late Eocene to early Oligocene freshwaters: Geology, v. 33, p. 189-192, doi:10.1130/G21019.1.

Hopmans, E.C., Weijers, J.W.H., Schefuss, E., Herfort, L., Sinninghe Damste, J.S., and Schouten, S., 2004, A novel proxy for terrestrial organic matter in sediments based on branched and isoprenoid tetraether lipids: Earth and Planetary Science Letters, v. 224, p. 107-116, doi:10.1016/j.epsl.2004.05.012.

Houben, A.J.P., van Mourik, C.A., Montanari, A., Coccioni, R., and Brinkhuis, H., 2011, The Eocene-Oligocene transition: Changes in sea level, temperature or both?: Palaeogeography, Palaeoclimatology, Palaeoecology, In press., doi:10.1016/j.palaeo.2011.04.008.

Ivany, L.C., Patterson, W.P., and Lohmann, K.C, 2000, Cooler winters as a possible cause of mass extinctions at the Eocene/Oligocene boundary: Nature, v. 407, p. 887-890, doi:10.1038/35038044.

Katz, M.E., Miller, K.G., Wright, J.D., Wade, B.S., Browning, J.V., Cramer, B.S., and Rosenthal, Y., 2008, Stepwise transition from the Eocene greenhouse to the Oligocene icehouse: Nature Geoscience, v. 1, p. 329-334, doi:10.1038/ ngeo179.

Keigwin, L.D., and Corliss, B.H., 1986, Stable isotopes in late middle Eocene to Oligocene foraminifera: Geological Society of America Bulletin, v. 97, p. 335-345, doi:10.1130/00167606(1986)97<335:SIILME>2.0.CO;2.

Kennett, J.P., and Shackleton, N.J., 1976, Oxygen isotopic evidence for the development of the psychrosphere 38 Myr ago: Nature, v. 260, p. 513-515, doi:10.1038/260513a0.

Kim, J.-H., van der Meer, J., Schouten, S., Helmke, P., Willmott, V., Sangiorgi, F., Koç, N., Hopmans, E.C., and Sinninghe Damsté, J.S., 2010, New indices and calibrations derived from the distribution of crenarchaeal isoprenoid tetraether lipids: Implications for past sea surface temperature reconstructions: Geochimica et
Cosmochimica Acta, v. 74, p. 4639-4654, doi:10.1016/j.gca.2010.05.027.

Kobashi, T., Grossman, E.L., Yancey, T.E., and Dockery, D.T., 2001, Reevaluation of conflicting Eocene tropical temperature estimates: Molluscan oxygen isotope evidence for warm low latitudes: Geology, v. 29, p. 983-986, doi:10.1130/0091 -7613(2001)029<0983:ROCETT>2.0.CO;2.

Kohn, M., Josef, J.A., Madden, R., Kay, R., Vucetich, G., and Carlini, A.A., 2004, Climate stability across the Eocene-Oligocene transition, southern Argentina: Geology, v. 32, p. 621624, doi:10.1130/G20442.1.

Lear, C.H., Bailey, T.R., Pearson, P.N., Coxall, H.K., and Rosenthal, Y., 2008, Cooling and ice growth across the Eocene-Oligocene transition: Geology, v. 36, p. 251-254, doi:10.1130/ G24584A.1.

Liu, Z., Pagani, M., Zinniker, D., DeConto, R., Huber, M., Brinkhuis, H., Shah, S.R., Leckie, R.M., and Pearson, A., 2009, Global cooling during the Eocene-Oligocene climate transition: Science, v. 323, p. 1187-1190, doi:10.1126/ science. 1166368.

Mancini, E.A., and Waters, L.A., 1986, Planktonic foraminiferal biostratigraphy of upper Eocene and lower Oligocene strata in southern Mississippi and southwestern and south-central Alabama: Journal of Foraminiferal Research, v. 16, p. 24-33, doi:10.2113/gsjfr.16.1.24.

Miller, K.G., Wright, J.D., and Fairbanks, R.G., 1991, Unlocking the Ice House: Oligocene-Miocene oxygen isotopes, eustacy and margin erosion: Journal of Geophysical Research, v. 96, B4, p. 6829-6848, doi:10.1029/90JB02015.

Miller, K.G., Browning, J.V., Aubry, M.-P., Wade, B.S., Katz, M.E., Kulpecz, A.A., and Wright, J.D., 2008, Eocene-Oligocene global climate and sea-level changes: St. Stephens Quarry, Alabama: Geological Society of America Bulletin, v. 120, p. 34-53, doi:10.1130/B26105.1.

Miller, K.G., Wright, J.D., Katz, M.E., Wade, B.S., Browning, J.V., Cramer, B.S., and Rosenthal, Y., 2009, Climate threshold at the Eocene-Oligocene transition: Antarctic ice sheet influence on ocean circulation: Geological Society of America. Special Paper, v. 452, p. 169-178, doi:10.1130/2009.2452(11).

Pearson, P.N., McMillan, I.K., Wade, B.S., Dunkley Jones, T., Coxall, H.K., Bown, P.R., and Lear, C.H., 2008, Extinction and environmental change across the Eocene-Oligocene boundary in Tanzania: Geology, v. 36, p. 179-182, doi:10.1130/G24308A.1

Pearson, P.N., Foster, G.L., and Wade, B.S., 2009, Atmospheric carbon dioxide through the EoceneOligocene climate transition: Nature, v. 461, p. 1110-1113, doi:10.1038/nature08447.

Prothero, D.R., Ivany, L.C., and Nesbitt, E.A., eds., 2003, From Greenhouse to Icehouse: The Marine Eocene-Oligocene Transition: New York, Columbia University Press, $541 \mathrm{p}$.

Pusz, A.E., Thunell, R.C., and Miller, K.G., 2011, Deep water temperature, carbonate ion, and ice volume changes across the Eocene-Oligocene climate transition: Paleoceanography, v. 26, p. PA2205, doi:10.1029/2010PA001950.

Rayner, N.A., Parker, D.E., Horton, E.B., Folland, C.K., Alexander, L.V., Rowell, D.P., Kent,
E.C., and Kaplan, A., 2003, Globally complete analyses of sea surface temperature, sea ice and night marine air temperature, 1871-2000: Journal of Geophysical Research, v. 108, p. 4407, doi:10.1029/2002JD002670.

Schouten, S., Eldrett, J., Greenwood, D.R., Harding, I., Bass, M., and Sinninghe Damsté, J.S., 2008, Onset of long-term cooling of Greenland near the Eocene-Oligocene boundary as revealed by branched tetraether lipids: Geology, v. 36, p. 147-150, doi:10.1130/G24332A.1.

Sheldon, N.D., 2009, Nonmarine records of climatic change across the Eocene-Oligocene transition, in Koeberl, C., and Montanari, A., The Late Eocene Earth-Hothouse, Icehouse, and Impacts: Geological Society of America Special Paper 452, p. 249-260.

van Andel, T.H., and Moore, T.C., Jr., 1974, Cenozoic calcium carbonate distribution and calcite compensation depth in the central equatorial $\mathrm{Pa}$ cific: Geology, v. 2, p. 87-92, doi:10.1130/0091 -7613(1974)2<87:CCCDAC>2.0.CO;2.

Wade, B.S., and Pearson, P.N., 2008, Planktonic foraminiferal turnover, diversity fluctuations and geochemical signals across the Eocene/ Oligocene boundary in Tanzania: Marine Micropaleontology, v. 68, p. 244-255, doi:10.1016/j .marmicro.2008.04.002.

Wang, C., and Enfield, D.B., 2001, The tropical Western Hemisphere warm pool: Geophysical Research Letters, v. 28, p. 1635-1638, doi:10.1029/2000GL011763.

Weijers, J.W.H., Schouten, S., Spaargaren, O.C., and Sinninghe Damsté, J.S., 2006, Occurrence and distribution of tetraether membrane lipids in soils: Implications for the use of the TEX86 proxy and the BIT index: Organic Geochemistry, v. 37 , p. $1680-1693$, doi:10.1016/j .orggeochem.2006.07.018.

Wilkinson, B.H., and Algeo, T.J., 1989, Sedimentary carbonate record of calcium magnesium cycling: American Journal of Science, v. 289, p. 1158-1194, doi:10.2475/ajs.289.10.1158.

Xiao, G.Q., Abels, H.A., Yao, Z.Q., Dupont-Nivet, G., and Hilgen, F.J., 2010, Asian aridification linked to the first step of the Eocene-Oligocene climate transition (EOT) in obliquitydominated terrestrial records (Xining Basin, China): Climate of the Past, v. 6, p. 501-513, doi:10.5194/cp-6-501-2010.

Zachos, J.C., Quinn, R.M., and Salamy, K., 1996, High resolution (104 yr) deep-sea foraminiferal stable isotope records of the Eocene-Oligocene climate transition: Paleoceanography, v. 11, p. 251-266, doi:10.1029/96PA00571.

Zanazzi, A., Kohn, M.J., MacFadden, B.J., and Terry, D.O., Jr., 2007, Large temperature drop across the Eocene-Oligocene transition in central North America: Nature, v. 445, p. 639-642, doi:10.1038/nature05551.

Manuscript received 21 June 2011

Revised manuscript received 8 September 2011

Manuscript accepted 19 September 2011

Printed in USA 